\title{
Polityka antykryzysowa Unii Europejskiej w obliczu pandemii SARS CoV-2 w obszarze zdrowia publicznego w 2020 roku. W poszukiwaniu rozwiązań funkcjonalnych
}

\section{Wprowadzenie}

Kryzys pandemiczny postawił przed Unią Europejką problem nowego typu. Pojawiło się pytanie o to jaka powinna być właściwa reakcja na takie zagrożenie. Zagrożenie biologiczne dotyczące życia i zdrowia Europejczyków. Na jakim poziomie powinny być podejmowane strategiczne, kluczowe działania. Wskazywano na to, że w dziedzinie zdrowia publicznego kompetencje UE są tylko uzupełniające wobec państw członkowskich. To państwa przede wszystkim ponoszą odpowiedzialność w tym zakresie i to one powinny wdrażać właściwe strategie. Jak zauważa B. Góralczyk ostatnie kryzysy, jakie dotknęły UE, wzmocniły raczej państwa narodowe niż struktury unijne, co jeszcze bardziej wskazywało na to, że poziom działania państwa będzie tym właściwym w tej sytuacji (Góralczyk, 2021, s. 42-58). Jednak wraz z rozwojem pandemii, jej transgranicznym i bezprecedensowym charakterem pojawiło się wyczekiwanie działań ze strony instytucji unijnych.

Pierwszym krajem, który doświadczył konsekwencji pandemii SARS CoV-2 w Europie były Włochy. Jak zauważa P. Matei z perspektywy tego kraju widoczny był brak koordynacji działań na poziomie europejskim. Natomiast państwa członkowskie (podobnie jak w przypadku kryzysu migracyjnego) zaczęły przygotowywać strategie antykryzysowe na poziomie państwowym (Pandemia, 2020). Ostatecznie jednak, jak zauważa J. Zielonka, państwa ,zrzuciły odpowiedzialność na Europę, która nie mogła jej unieść, ponieważ nie otrzymała od państw narodowych odpowiednich uprawnień" (Wszyscy, 2020). Jego zdaniem wyzwanie związane z pandemią wymaga skoordynowanych działań na wielu poziomach (od lokalnego do europejskiego) i decyzji zarówno technokratycznych, jak i uwzględniających interes polityczny. Podkreśla on (w duchu funkcjonalizmu) znaczenie różnorodnych specjalistycznych agencji, które są bliżej problemów, które trzeba rozwiązać ${ }^{1}$. Zauważa jednak napięcie między władzą polityczną państw a merytokratycznym porządkiem agencji. „Władza opiera się zatem na trzymaniu klucza do tajemnicy przyszłości, która jest konstytutywnym elementem

1 „Z jednej strony, trzeba obalić monopol państw na decyzje, a z drugiej - rozproszyć władzę na poziomie europejskim. Poważną część uprawnień centralnych organów UE należy przekazać do ponad 40 organów regulacyjnych Europy, które już istnieją i są porozrzucane po całym kontynencie. W Polsce jest Frontex, w Amsterdamie jest EMA (Europejska Agencja Leków), zaś Europejska Agencja do spraw Ochrony Środowiska jest w Kopenhadze” (Wszyscy, 2021). 
gry o kontrolę sfer niepewności” (Rossa, Marcinkowski, 2020, s. 26). Działania Komisji Europejskiej i innych instytucji unijnych, a także rządów państw członkowskich zawsze więc będą próbą kontrolowania tej niepewności.

Kryzysy, jakie dotknęły w ostatnim czasie Unię Europejską, szczególnie od kryzysu ekonomicznego w 2008 roku stały się powodem ożywienia dyskusji o dalszym kierunku integracji europejskiej. Podstawowe pytanie dotyczy tego czy rozwiązania antykryzysowe prowadzą do wzmocnienia drogi do federalizacji UE czy też wzmacniają międzyrządowość (zob. Tosiek, 2019, s. 47-58; Tosiek, 2018, s. 79-98; Mieńkowska-Norkiene, 2020, s. 35-55). Nie próbując rozstrzygnąć tego sporu warto w sytuacji kryzysu pandemicznego zastanowić się na ile podejście w duchu funkcjonalistycznym jest obecne w europejskiej odpowiedzi na kryzys pandemiczny.

Rozwiązywania problemów, jakie przyniosła pandemia, poszukiwano na różnych poziomach. Podobnie jak w przypadku innych kryzysów, jakie dotknęły w ostatnim czasie UE, wielu polityków i komentatorów (szczególnie prawicowych) oczekiwało działań przede wszystkim na poziomie państwa. W tej perspektywie upatrywano szansy na wzmocnienie państw narodowych jako właściwego podmiotu działań antykryzysowych. Przy początkowym braku zdecydowanych działań ze strony instytucji UE w pierwszym okresie pandemii wydawało się, że będzie to opcja dominująca. Tym bardziej, że zdrowie publiczne pozostaje w domenie działania państw członkowskich, a działania UE są tutaj tylko uzupełniające. Skala zagrożenia, jego ponadgraniczny charakter oraz słabość reakcji państw zwróciły jednak uwagę na poziom europejski. Wynikało to z jednej strony z obiektywnych trudności budowania odpowiedniej strategii na poziomie państw. $Z$ drugiej zaś strony z chęci współdzielenia problemu i odpowiedzialności (w tym także porażek). Politycy krajowi zadziałali tu zgodnie z zasadą nacjonalizacji sukcesu i europeizacji porażki (nawet jeśli tylko potencjalnej) (Foster, Grzymski, Brusenbauch Meislová, 2021, s. 75-86).

W procesie podejmowania decyzji uwzględniano zarówno podejście polityczne, jak i merytoryczne. W tym pierwszym uwzględniając argumentacje i opis sytuacji przedstawiany przez specjalistów (szczególnie epidemiologów) brano pod uwagę także uwarunkowania ekonomiczne, społeczne oraz potencjalne zyski czy straty polityczne. Gremia niepolityczne - eksperckie (na czele z Europejską Agencją Leków) zajmujące się problematyką pandemii przynajmniej w teorii tego ostatniego czynnika politycznego uwzględniać nie musiały. Można więc zakładać, że ich decyzje w większym stopniu miały charakter funkcjonalny.

Celem artykułu jest ukazanie reakcji Unii Europejskiej w obszarze zdrowia publicznego na kryzys pandemiczny w pierwszym roku pandemii. W oparciu o hermeneutykę (Surmaczyński, 2010, s. 95-96) dokumentów unijnych zostaną ukazane główne kierunki proponowanych działań. Głównym problemem badawczym artykułu będzie weryfikacja twierdzenia o poszukiwaniu rozwiązań funkcjonalnych w analizowanych działaniach antykryzysowych. Dodatkowo zostanie postawione pytanie badawcze o wpływ pandemii na rozwój unijnej polityki zdrowotnej (np. EU4Health czy strategię farmaceutyczną). Prowadzone badanie dotyczy zjawiska w trakcie jego trwania, stąd konieczność określenia cezury czasowej jaką będzie rok 2020 . 


\section{Czego uczy nas funkcjonalizm?}

Funkcjonalizm w teorii integracji europejskiej jest kojarzony z nazwiskiem Davida Mitrany’ego. Nie należy jednak utożsamiać politologicznej wersji funkcjonalizmu z tą znaną z socjologii czy antropologii. Jednak, jak zauważa S. Konopacki, wspólna dla tych podejść jest „,koncepcja «potrzeby» i jej zaspokojenie poprzez adaptację strukturalną" (Konopacki, 1998a, s. 61). Logika działania wynikająca z takiego podejścia jest więc wysoce utylitarystyczna i pragmatyczna. Punktem wyjścia funkcjonalizmu jest odniesienie do konkretnie zdefiniowanego problemu czy zadania i zastosowanie określonych do tego rozwiązań. „Funkcjonalizm podkreśla ważność tezy, wszelkie związki i współzależności winny kształtować się stosownie do wymogów potrzeb oraz funkcji” (Konopacki, 1998, s. 63). Realizacja tych założeń, o ile byłaby w ogóle możliwa stoi w sprzeczności z tradycyjnie rozumianym porządkiem władzy z wiodącą rolą władzy państwowej. Jak zauważa J. Ruszkowski „,każde scedowanie cząstki funkcji państwa narodowego na poziom organizacji ponadnarodowych i ich instytucji kierowniczych ogranicza jego narodowe kompetencje i zarazem wzmacnia funkcjonalne instytucje i agencje międzynarodowe jako struktury formalne" (Ruszkowski, 2007, s. 99).

Podejście w duchu funkcjonalizmu wydaje się adekwatne w sytuacji zagrożenia transgranicznego dla zdrowia. W podejściu tym bowiem deprecjonuje się znaczenie terytorialności na rzecz rozwiązań funkcjonalnych, które z założenia mają (czy też mogą mieć w zależności od potrzeby) charakter transgraniczny. Jak zauważa P. J. Borkowski, cytując D. Mitrany’ego „Dana funkcja sama określa właściwe organy [jej wykonywania]. Ujawnia także poprzez praktykę rodzaj akcji, które muszą być w danych warunkach podejmowane i w ten sposób określa kompetencje im niezbędne" (Borkowski, 2007, s. 74; zob. także Czaputowicz, 2008, s. 117-120; Czaputowicz, 2018, s. 31-36). W modelowych warunkach pozapolitycznych zarządzanie kryzysem pandemicznym powinno więc być w rękach specjalistycznych agencji działających technokratycznie. W świecie politycznym taki model zarządzania w czystej postaci nie jest możliwy. Warto jednak zwrócić uwagę na przykład Szwecji, która przez długi czas prowadziła zarządzanie kryzysem covidowym w oparciu o technokratyczne czy bardziej merytokratyczne wskazania głównego epidemiologa kraju. W praktyce innych krajów, a także na poziomie UE mamy do czynienia z działaniami merytokratycznymi w duchu funkcjonalnym oraz decyzjami politycznymi (często także niepozbawionymi racji merytorycznych).

\section{Od reakcji ad hoc do strategii szczepień UE}

Rola UE w obszarze zdrowia publicznego ma charakter uzupełniający wobec działań państw członkowskich. Koordynacja działań w tym obszarze jest jednak niezbędną konsekwencją swobodnego przepływu osób i towarów na rynku wewnętrznym. Współpraca UE w tym zakresie służy stawianiu czoła wspólnym wyzwaniom zdrowotnym w myśl artykułu 168 TFUE. Należy zauważyć, że Traktat wymienia tu wprost 
zwalczanie pandemii oraz monitorowanie transgranicznych zagrożeń dla zdrowia. Dlatego też od początku pojawiło się oczekiwanie co do wspólnych działań wobec zagrożenia związanego z koronawirusem.

Od samego początku kryzysu pandemicznego Komisja Europejska współpracuje z państwami członkowskimi. Działania te dotyczą przede wszystkim zapewnienia odpowiedniego zaopatrzenia medycznego oraz dostępności środków ochrony osobistej dla służb zajmujących się SARS CoV-2, wspieranie badań i innowacji w zakresie terapii i szczepionek oraz wspieranie zwiększania zdolności produkcyjnych szczepionek. Istotnym obszarem wymagającym pilnego wsparcia ze strony Komisji Europejskiej są badania naukowe i wdrożeniowe dotyczące leków i szczepionki. Pierwsze działania z tym związane zostały podjęte już na przełomie stycznia i lutego 2020 roku (Coronavirus: EU mobilises, 2020). Finansowanie uzyskało wówczas 17 projektów, w których uczestniczy 136 zespołów badawczych z UE i innych krajów. Dotyczą one: nowych szczepionek, nowych metod leczenia, szybkich i wiarygodnych testów diagnostycznych oraz lepszych systemów monitorowania sytuacji epidemicznej (COVID-19: Commission steps up, 2020).

W marcu 2020 roku Komisja Europejska powołała ekspercki panel naukowy do spraw pandemii (E03719). W jego skład weszło początkowo siedmiu ekspertów z zakresu epidemiologii i wirusologii. Obecnie (marzec 2021) w skład panelu wchodzą: A. Fontanet, Ch. Drosten, F. S. Soria, K. Mølbak, L. H. Wieler, M. R. Capobianchi, M. Koopmans, M.. Szócska, P. Piot. Członkowie są powoływani jako osoby prywatne (a nie reprezentanci instytucji czy podmiotów medycznych) i działają niezależnie oraz w interesie publicznym Unii. Panel zajmuje się w szczególności doradztwem w zakresie: sformułowania adekwatnych środków reagowania oraz zdiagnozowania braków, czy niespójności w działaniach służących powstrzymaniu rozprzestrzeniania się koronawirusa, kwestii zarządzania klinicznego i leczenia, a także lepszej koordynacji zarządzania kryzysowego na poziomie unijnym² ${ }^{2}$. Prace panelu są wspierane przez platformę doradztwa naukowego w zakresie Covid-19 z udziałem specjalistów naukowych z państw członkowskich. Działanie to jest realizacją funkcjonalnego podejścia zakładającego dostosowanie reakcji do określonej potrzeby. Komisja Europejska uruchomiła też specjalną platformę internetową służącą gromadzeniu i udostępnianiu danych przydatnych w badaniach nad koronawirusem (www. covid19dataportal.org).

Bardzo ważną inicjatywną Komisji Europejskiej były dążenia do stworzenia i następnie zakupu szczepionki przeciw wirusowi SARS CoV-2. Od samego początku wskazywano, że jest to jeden z priorytetów działań antypandemicznych (zob. Veugelers, Zachmann, 2020). W tym celu nie tylko wspierano programy badawcze, ale także prowadzono rozmowy z przedsiębiorstwami z branży biotechnologicznej. Negocjowano z wieloma podmiotami farmaceutycznymi. Komisja Europejska podpisała w 2020 roku umowy dotyczące zakupu określonych ilości dawek szczepionki (po jej stworzeniu i dopuszczeniu na rynek UE) z takimi podmiotami jak:

${ }^{2}$ Szczegółowe informacje na ten temat znajdują się na stronie https://ec.europa.eu/health/advisorypanel_covid19_en, 3.11.2020. 
Sanofi-GSK ${ }^{3}$, Astra Zeneca ${ }^{4}$, Johnson \& Johnson ${ }^{5}$, CureVac ${ }^{6}$, Moderna ${ }^{7}$, BioNTech-Pfizer ${ }^{8}$.

W dniu 17 czerwca 2020 roku Komisja Europejska przedstawiła unijną strategię dotyczącą szczepionek. Przedstawiony dokument wskazywał na trzy kluczowe cele: zapewnienie skutecznych i bezpiecznych szczepionek wysokiej jakości, zabezpieczenie szybkiego dostępu do nich mieszkańcom państw członkowskich oraz zapewnienie jak najszybciej sprawiedliwego dostępu do przystępnych cenowo szczepionek na całym świecie. Działania Unii służące realizacji tych celów opierają się na dwóch filarach: zabezpieczeniu wystarczającej produkcji szczepionek na terenie UE oraz wystarczających dostaw do państw członkowskich, a także dostosowania ram prawnych do obecnej kryzysowej sytuacji i wykorzystanie istniejącej już elastyczności regulacyjnej (EU Strategy for COVID-19, 2020).

W analizowanym dokumencie strategicznym Komisja zwróciła uwagę na konieczność zastosowania szczególnego podejścia ze względu na szczególną sytuację. Wskazano na potrzebę maksymalnego skrócenia okresów prac rozwojowych nad szczepionkami, dywersyfikacje ryzyka finansowego związanego z pracami badawczo-rozwojowymi oraz zwiększeniem zdolności produkcyjnych i możliwości pozyskiwania surowców oraz ułatwieniu we wprowadzeniu gotowych szczepionek na rynek unijny. Podkreślono wagę wspólnych działań, które pozwolą na uniknięcie konkurencji między państwami członkowskimi. Jako przykład takiej inkluzyjnej współpracy wskazano działania w ramach sojuszu na rzecz szczepionek utworzonego przez Francję, Niemcy, Włochy i Niderlandy, które są kontynuowane przez Komisję Europejską.

W analizowanym dokumencie znalazły się także zapisy dotyczące ogólnych warunków w zakresie umów zakupu szczepionek. Wskazano tam, że takie umowy zakupu z wyprzedzeniem będą realizowane za pośrednictwem instrumentu wsparcia w sytuacjach nadzwyczajnych (EU Strategy for COVID-19, 2020). Określono także, że gdy powstanie skuteczna i bezpieczna szczepionka, państwa członkowskie będą mogły ją nabyć bezpośrednio od producenta zgodnie z warunkami zawartej przez

${ }^{3}$ Coronavirus: Commission concludes talks to secure future coronavirus vaccine for Europeans, European Commission - Press Release, Brussels 31 July 2020, https://ec.europa.eu/commission/ presscorner/detail/en/ip_20_1439, 21.10.2020.

${ }^{4}$ Coronavirus: Commission reaches first agreement on a potential vaccine, European Commission - Press Release, Brussels 14 August 2020, https://ec.europa.eu/commission/presscorner/detail/ en/ip_20_1438, 21.10.2020.

${ }^{5}$ Coronavirus: Commission concludes further talks to secure future vaccine, European Commission - Press Release, Brussels 13 August 2020, https://ec.europa.eu/commission/presscorner/ detail/\%5Beuropa_tokens:europa_interface_language\%5D/ip_20_1481, 21.10.2020.

${ }^{6}$ Coronavirus: Commission continues expanding future vaccines portfolio with new talks, European Commission - press Release 20 August 2020, https:/ec.europa.eu/commission/presscorner/ detail/en/IP 20 1494, 22.03.2021.

${ }^{7}$ Coronavirus: Commission expands talks to a fifth vaccine manufacturer, European Commission - Press Release, Brussels 24 August 2020, https://ec.europa.eu/malta/news/coronavirus-commission-expands-talks-fifth-vaccine-manufacturer_en, 21.10.2020.

${ }^{8}$ Coronavirus: Commission completes vaccines portfolio following talks with a sixth manufacturer, European Commission - Press Release, Brussels 9 September 2020, https://ec.europa.eu/commission/presscorner/detail/en/ip_20_1556, 21.10.2020. 
Komisję wcześniejszej umowy. Przydział ilości szczepionek dla państw UE będzie uwzględniał liczbę ludności.

W tej szczególnej sytuacji Komisja wskazała na potrzebę elastyczności w procesie zatwierdzenia szczepionek na rynek europejski przy jednoczesnej dbałości o wysoki poziom bezpieczeństwa i rzetelną ocenę ich skuteczności na podstawie „wystarczająco solidnych danych". Należy jednak działać na tyle elastycznie, aby przyspieszyć udzielanie pozwoleń i umożliwić dostępność szczepionek w państwach UE. W tym celu Europejska Agencja Leków powołała specjalną grupę zadaniową (ETF) w celu pomocy firmom pracującym nad szczepionkami. Grupa ta zapewnia: doradztwo naukowe i informacje zwrotne na temat planów prac rozwojowych, wspiera naukowo prowadzenie badań klinicznych w UE oraz oferuje bieżący przegląd napływających danych naukowych, co ma przyspieszyć ocenę ostatecznych danych po zakończeniu badań. Działania te mają na celu maksymalnie skrócić czas oczekiwania na stosowne pozwolenia przy jednoczesnym uwzględnieniu kryteriów skuteczności i bezpieczeństwa badanych produktów leczniczych. Szczególna rola Europejskiej Agencji Leków i jej znaczenie $\mathrm{w}$ zarządzaniu kryzysem pandemicznym jest reakcją nawiązującą do propozycji funkcjonalnych.

Komisja w odniesieniu do szczepionek na Covid-19 przewiduje udzielenie pozwolenia warunkowego. Jest ono udzielane w oparciu o mniej wyczerpujące dane niż w przypadku procedury standardowej, przy uwzględnieniu, że stosunek korzyści do ryzyka jest pozytywny. Przedsiębiorstwa, które uzyskają takie pozwolenie mają obowiązek uzupełnić brakujące dane w późniejszym okresie. Dla przyspieszenie procesu wejścia szczepionek na rynek UE Komisja zaproponuje także państwom członkowskim, aby dokumenty zostały przetłumaczone na wszystkie języki UE dopiero po zatwierdzeniu produktu. Podobna propozycja dotyczy opakowań i etykietowania ( $E U$ Strategy for COVID-19, 2020).

W toku dalszych działań Komisja Europejska w lipcu 2020 przedstawiła dokument „Krótkoterminowa gotowość UE w dziedzinie zdrowia na wypadek występowania ognisk COVID-19". Podsumowywał on doświadczenia dotychczasowego przebiegu kryzysu oraz podkreślał konieczność wykorzystania środków opartych na podstawach naukowych i poddanych testom w warunkach skrajnych w celu przygotowania się na kolejne fale pandemii i budowania odporności na takie zagrożenia w przyszłości. Za najważniejsze obszary wymagające intensywnych działań uznano: testowanie, ustalanie kontaktów, nadzór nad zdrowiem publicznym, dostęp do środków ochrony osobistej, leków i wyrobów medycznych, wsparcie grup szczególnie wrażliwych, ograniczenie występowania grypy sezonowej oraz zwiększenie wydolności systemów opieki zdrowotnej na wypadek skokowego wzrostu ilości hospitalizacji (Krótkoterminowa, 2020).

Komisja Europejska wskazała na podstawowe znaczenie testowania dla ograniczania zasięgu pandemii. Zwrócono uwagę, że dotychczasowe zasoby, jakimi dysponowały państwa członkowskie okazały się w wielu przypadkach niewystarczające. Podkreślono konieczność powiększenia zdolności w zakresie testowania w związku z podejrzeniem zakażenia SARS CoV-2 (w tym wykorzystanie druku 3D sprzętu do testów). Komisja uruchomiła w związku z tym zamówienie wspólne na zaopatrzenie laboratoryjne. Zalecono także, aby zwiększyć możliwości testowania pacjentów ską- 
poobjawowych oraz osób, które miały kontakt z pacjentami z potwierdzonym wynikiem testu. Należy jednak zauważyć, że realizacja tych zaleceń była zróżnicowana i zależała do decyzji władz państwowych.

Dla zarządzania kryzysem pandemicznym niezbędne jest nie tylko testowanie, ale też ustalanie kontaktów osób zakażonych. W tym celu (podobnie jak m.in. w Chinach, Korei Południowej czy Japonii) można wykorzystać nowoczesne aplikacje mobilne. Wywołuje to jednak w Europie sporo kontrowersji ze względu na ochronę danych osobowych i kwestię prywatności. Komisja jednak zaleca stosowanie takich narzędzi. Jak zapisano w analizowanym dokumencie: „Łączenie standardowych metod ustalania kontaktów zakaźnych i interoperacyjnych aplikacji mobilnych («aplikacji») może umożliwić skuteczniejsze przerywanie nowych łańcuchów zakażeń i zapobiegać rozprzestrzenianiu się zakażeń w społecznościach przy jednoczesnym przestrzeganiu zasad ochrony danych określonych we właściwych przepisach" (Krótkoterminowa, 2020). Podkreślono także potrzebę interoperacyjności wszystkich aplikacji krajowych co powinno pozwolić na swobodne przekraczanie granic wewnętrznych w UE. Komisja Europejska wprowadziła też w tym okresie stosowne zmiany w odniesieniu do funkcjonowania sieci e-zdrowie (Decyzja wykonawcza Komisji (UE) 2020/1023). Zwróciła również uwagę na potrzebę wdrożenia środków gotowości w punktach wejścia do UE (porty, międzynarodowe porty lotnicze, międzynarodowe stacje kolejowe, lądowe przejścia graniczne).

Pandemia koronawirusa zwróciła także uwagę na globalizacyjny efekt na rynku produktów medycznych i leków. Widoczne, szczególnie w pierwszym okresie pandemii braki w tym zakresie stały się pretekstem do dyskusji o budowie strategicznej autonomii w zakresie zdrowia publicznego w UE (Sipiczki, Lanno, 2021). Dodatkowym problemem było rozpowszechnianie produktów niezgodnych z przepisami, podrobionych i niebezpiecznych. Komisja Europejska podjęła od stycznia 2020 roku szereg działań w tym zakresie. Należały do nich m.in. uruchomienie zamówień wspólnych, stworzenie zapasów strategicznych (rescUE), uruchomienie środków na adaptacje przemysłu, monitorowanie niedoborów (wspólnie z Europejską Agencją Leków), pozwolenia na wywóz (Rozporządzenie wykonawcze Komisji (UE) 2020/568, 2020) oraz swobodny dostęp do norm?.

Zwiększone zapotrzebowanie na wyroby medyczne i sprzęt ochrony osobistej stał się też poważnym wyzwaniem finansowym dla państw członkowskich. Dlatego też Komisja Europejska podjęła decyzję umożliwiającą państwom zawieszenie należności celnych i podatku VAT na środki ochrony osobistej, respiratory czy zestawy do testów (Decyzja Komisji (UE) 2020/491, 2020). Dla uniknięcia ponownej sytuacji niedoborów Komisja przyjęła też wytyczne w sprawie ograniczeń wywozowych oraz optymalnego zaopatrzenia $\mathrm{w}$ leki ${ }^{10}$. Utworzono także specjalną platformę koordynacyjną do spraw sprzętu medycznego, która ma służyć wymianie informacji między Komisją a państwami członkowskimi. Ma to pozwolić na lepsze określanie popytu i podaży

${ }^{9}$ Były to normy dotyczące medycznych masek twarzowych i masek ochronnych, rękawic, odzieży i respiratorów w celu wspierania produkcji i wprowadzania do obrotu podstawowego zaopatrzenia tymczasowo oferowane przez CEN i CENELEC.

${ }^{10}$ Wytyczne określone w załączniku 2 do komunikatu w sprawie skoordynowanej reakcji gospodarczej na epidemię COVID-19: COM(2020) 112 z 13.3.2020. 
oraz być wsparciem ułatwiającym monitorowanie i docelowo zwiększanie zdolności produkcyjnych w tym zakresie w państwach członkowskich.

Zwrócono także uwagę na szczególne potrzeby grup szczególnie wrażliwych. Zaliczono do nich: osoby starsze, dotknięte chorobami cywilizacyjnymi (np. cukrzyca, otyłość), osoby zmarginalizowane społecznie oraz pracownicy wykonujący zawód związany z kontaktem z chorymi na Covid-19. Sytuacja tych grup jest wysoce zróżnicowana wymaga też zastosowania różnorodnych działań. W przypadku pracowników sektorów wrażliwych zwracano uwagę nie tylko na ich narażenie na zakażenie (jak w przypadku pozostałych grup wrażliwych), ale i na przeciążenie pracą w warunkach kryzysowych. W przypadku grup zmarginalizowanych zauważono też wzrost przemocy domowej oraz zagrożenie ubóstwem.

W październiku 2020 roku Komisja Europejska opublikowała kolejny dokument w tym zakresie: „Gotowość w obszarze strategii szczepień i wprowadzania szczepionek przeciw Covid-19". Zwrócono w nim uwagę na to, że dotychczasowe działania nie pozwoliły na opanowanie i ograniczenie rozwoju pandemii. Dlatego jako szansę na skuteczne powstrzymanie kryzysu zdrowotnego wskazano wprowadzenie szczepień oraz dalsze stosowanie odpowiednich i opartych na dowodach naukowych środków hamujących rozprzestrzenianie się wirusa (Preparedness, 2020).

Komisja wskazała na potrzebę dalszych rozmów mających na celu zawarcie umów z producentami prowadzącymi badania nad szczepionkami. W tym okresie zostały już podpisane trzy umowy z firmami: Astra Zeneca na $300 \mathrm{mln}$ dawek, Sanofi-GSK na $300 \mathrm{mln}$ dawek oraz Johnson\&Johnson na $200 \mathrm{mln}$ dawek. Skoordynowane podejście do dystrybucji szczepionek, zgodnie z przyjętymi wcześniej zasadami ma zapewnić dostęp do szczepionek dla wszystkich państw w tym samym czasie. W związku z nasilającymi się od początku pandemii działaniami dezinformacyjnymi Komisja uznała za ważne spójne i przejrzyste rozpowszechnianie informacji na temat szczepionek oraz walkę z dezinformacją (zob. także Walka, 2020). W analizowanym dokumencie ponownie podkreślono konieczność zapewnienia odpowiednich rygorów w zakresie kontroli skuteczności i bezpieczeństwa w trakcie procesu rejestracji szczepionek przy jednoczesnej maksymalnej elastyczności regulacyjnej i wsparciu ze strony unijnej. Zwrócono uwagę także na szczególne znaczenie zwiększonego monitorowania bezpieczeństwa i skuteczności szczepionek już po zatwierdzeniu do obrotu w UE.

Komisja Europejska zaproponowała także kryteria określania grup priorytetowych w zakresie szczepień. Państwa członkowskie powinny uwzględnić wpływ na spowolnienie rozprzestrzeniania się i ostateczne powstrzymanie pandemii oraz ochronę grup najbardziej narażonych. Biorąc pod uwagę powyższe kryteria wskazano personel z obszaru zdrowia publicznego zaangażowany w zwalczanie pandemii oraz grupy wiekowe, które najbardziej ucierpiały w trakcie dotychczasowego przebiegu pandemii. Zauważono jednocześnie, że dalsza szczegółowa priorytetyzacja będzie związana ze specyfiką i właściwościami produktów dopuszczanych do szczepień na rynek UE. Dodatkowym kryterium rozstrzygającym będzie informacja na temat bezpieczeństwa i skuteczności w określeniu do konkretnych grup społecznych np. ze względu na wiek. 


\section{Kryzys pandemiczny a Unia dla zdrowia i unijna strategia farmaceutyczna}

Kryzys pandemiczny miał wpływ także na zmiany w zakresie unijnego programu dla zdrowia oraz strategii farmaceutycznej. W obu przypadkach poza dotychczasowymi kierunkami działań uwzględniono problemy wynikające $\mathrm{z}$ doświadczeń $\mathrm{z}$ pandemią SARS CoV-2. Unijne programy dotyczące zdrowia są realizowane od 2003 roku (zob. Ex-post, 2011). W dniu 28 maja 2020 roku KE zaproponowała nowy program „UE dla zdrowia” (UE4Health) (Wniosek Rozporzadzenie Parlamentu Europejskiego $i$ Rady w sprawie ustanowienia Programu działań Unii $w$ dziedzinie zdrowia na lata 2021-2027 oraz uchylenia rozporzadzenia (UE) nr 282/2014). Program został ustanowiony Rozporządzeniem Parlamentu Europejskiego i Rady z dnia 24 marca 2021 roku (Rozporzadzenie Parlamentu Europejskiego i Rady (UE) 2021/522). Nowy program dotyczący zdrowia w UE ma być nie tylko odpowiedzią na kryzys pandemiczny, ale posłużyć jako narzędzie budowania Unii bardziej odpornej na podobne zagrożenia w przyszłości. Program ma cztery cele ogólne: poprawa i wspieranie zdrowia w Unii Europejskiej, zwalczanie transgranicznych zagrożeń dla zdrowia, poprawa jakości produktów leczniczych, wyrobów medycznych i innych niezbędnych w sytuacjach kryzysowych oraz wzmocnienie systemów opieki zdrowotnej, ich odporności i zasobooszczędności. W ramach tych celów ogólnych zdefiniowano cele szczegółowe.

$\mathrm{W}$ celu drugim, który w największym stopniu jest bezpośrednio związany z pandemią wskazano trzy cele szczegółowe. Są to: działania związane z transgranicznymi zagrożeniami dla zdrowia (zapobieganie, gotowość), uzupełnianie krajowych zapasów produktów niezbędnych w sytuacjach kryzysowych oraz utworzenie rezerwy personelu medycznego, personelu opieki zdrowotnej i personelu pomocniczego. Program EU4Health ma być krokiem w stronę rzeczywistej Europejskiej Unii Zdrowotnej. Prowadzić do tego ma realizacja najbardziej pilnych priorytetów: reakcje na kryzys pandemiczny i budowanie odporności UE na transgraniczne zagrożenia dla zdrowia, europejski plan walki z rakiem oraz europejska strategia farmaceutyczna.

Opisywany program unijny dla zdrowia ma też przyczynić się do tworzenia rezerwy produktów niezbędnych w nadzwyczajnych sytuacjach kryzysowych. Ma to stanowić uzupełnienie działań prowadzonych w ramach rezerwy rescUE. Wsparciem także ma zostać objęte opracowanie unijnego systemu monitoringu, sprawozdawczości i powiadamiania o niedoborach, co ma pozwolić na lepsze zarządzanie i koordynacje działań w tym obszarze współpracy. Program ma też wspierać badania naukowe oraz wdrażanie nowych produktów leczniczych, szczególnie szczepionek i środków przeciwdrobnoustrojowych. Planowane działania mają też prowadzić do poprawy interoperacyjności systemów opieki zdrowotnej państw członkowskich. Przygotowaniu do podobnych jak obecna sytuacji kryzysowych ma służyć planowanie awaryjne, podnoszenie kwalifikacji pracowników służby zdrowia oraz ćwiczenia gotowości na wypadek zagrożeń, szczególnie o charakterze transgranicznym.

Kryzys pandemiczny zwrócił także uwagę rządzących na problem dostępności leków i rozwoju badań w tym obszarze. W dniu 25 listopada 2020 roku została przyjęta Strategia farmaceutyczna dla Europy. Jest ona odpowiedzią na niedobory uwidocznione przez kryzys pandemiczny i jednocześnie wskazuje cele rozwoju branży i kierunki wsparcia Komisji w powiązaniu z założeniami Europejskiego Zielonego Ładu, Euro- 
pejskiej Strategii Cyfrowej czy nowej Europejskiej Strategii Przemysłowej. Przyjęta strategia opiera się na czterech filarach. Pierwszy dotyczy zapewnienia pacjentom dostępu do leków po przystępnych cenach oraz zajęcie się niezaspokojonymi potrzebami medycznymi (np. w dziedzinie oporności na środki przeciwdrobnoustrojowe, czy chorób rzadkich), drugi dotyczy konkurencyjności, innowacji i zrównoważonego rozwoju przemysłu farmaceutycznego UE oraz opracowywanie bezpiecznych, skutecznych i bardziej ekologicznych leków wysokiej jakości. Trzeci filar jest bezpośrednio związany z pandemią i dotyczy wzmacniania mechanizmów gotowości i reagowania na sytuacje kryzysowe, zróżnicowanych i bezpiecznych łańcuchów dostaw oraz rozwiązywania problemu niedoborów leków. Natomiast czwarty filar zakłada zapewnienie silnego głosu UE na świecie poprzez promowanie wysokiego poziomu jakości, skuteczności i norm bezpieczeństwa (Strategia farmaceutyczna, 2020; zob. także A pharmaceutical, 2020).

Wśród innych działań związanych z pandemią, a dotyczących zdrowia publicznego i zarządzania kryzysowego Komisja Europejska zaproponowała także: wzmocnienie Europejskiej Agencji Leków oraz Europejskiego Centrum ds. Zapobiegania i Kontroli Chorób (ECDC), utworzenie europejskiej przestrzeni danych dotyczących zdrowia, wzmocnienie rescEU, zwiększenie środków finansowych na badania naukowe i rozwój w dziedzinie zdrowia, zwiększenie „Rezerwy na rzecz solidarności i pomocy nadzwyczajnej” (The Solidarity and Emergency Aid Reserve) oraz przygotowanie lepszych mechanizmów w zakresie gotowości na sytuacje kryzysowe i zarządzania kryzysowego na poziomie europejskim (Europe's, 2020).

\section{W poszukiwaniu rozwiązań funkcjonalnych w obliczu kryzysu zdrowotnego}

Jeżeli potraktować reakcje na kryzys w ujęciu funkcjonalizmu to możemy poszukiwać tu procesu racjonalnego uczenia się (Czachór, 2013, s. 47). Pojawiająca się potrzeba musi zostać rozpoznana i następnie musi wystąpić stosowna reakcja o ile jest ona niezbędna na poziomie europejskim. Mamy tu więc dwa możliwe momenty problemowe. Po pierwsze, należy odpowiednio zdiagnozować sytuację (rozpoznać potrzebę). Problemem jest gdzie takie rozpoznanie i określenie zapotrzebowania ma nastąpić. Uwzględniając pierwszoplanową rolę państw w obszarze zdrowia publicznego, to one są ,naturalnie” predystynowane do tej roli. Jednak transgraniczny charakter wyzwania wskazuje na konieczność ponadnarodowego stawiania diagnozy i poszukiwania odpowiedzi na problemy. Tym bardziej, że instytucje ponadnarodowe mają tutaj dużo lepszy, szerszy i szybszy dostęp do odpowiednich informacji (Czaputowicz, 2010, s. 252). Oczywiście działanie „ponad” czy bardziej „poza” państwami jest możliwe o ile państwa to zaakceptują i w takim zakresie na jaki się zgodzą. Po drugie, potrzebne są obiektywne kryteria oceny sytuacji co wiedzie nas do bardziej zobiektywizowanych i pozapolitycznych (pozapaństwowych) rozwiązań funkcjonalnych.

Jeżeli przyjmiemy za funkcjonalistami, że istnieje możliwość wydzielenia niepolitycznych aspektów potrzeb ludzkich możemy poszukiwać funkcjonalnych rozwiązań w zarządzaniu kryzysem pandemicznym (Czaputowicz, 2018, s. 31). Wydzielenie to 
może mieć charakter analityczny, związany z procesem podejmowania decyzji, a nie ontologiczny. Nie odnosząc się więc do podejmowanych w ramach funkcjonalizmu czy neofunkcjonalizmu prób ,poszukiwania ogólnej formuły integracji poprzez uporządkowanie funkcjonalnych współzależności między uczestnikami integracji europejskiej" (Czachór, 2013, s. 44), ale do samej logiki funkcjonalizmu warto wskazać na zastosowanie rozwiązań funkcjonalnych w zarządzaniu kryzysem pandemicznym w obszarze zdrowia publicznego w UE w 2020 roku. W myśl logiki funkcjonalizmu, problemy związane z pandemią wirusa SARS CoV-2 powinny być w dużej mierze rozwiązywane przez odpowiadające ich charakterowi instytucje, agencje czy powołane ad hoc zespoły. Szczególnie w obszarze zdrowia publicznego powinno to odbywać się pozapolitycznie. Choć jak zauważali neofunkcjonaliści, ważna jest nie tyle treść polityczna działań, ale metoda i kontekst podejmowania decyzji (Konopacki, 1998b, s. 111). Taki niepolityczny kontekst zapewniają pozapolityczne podmioty zarządzające określonymi problemami (np. Europejska Agencja Leków) czy też zespoły eksperckie, jak powołany przez Komisję Europejską panel naukowy.

Reakcja na kryzys w obszarze zdrowia publicznego jest o tyle skomplikowana, że odbywa się na wielu poziomach jednocześnie. Na poziomie państwa czy regionów poza logiką funkcjonalną mamy też logikę władzy. Na poziomie europejskim mamy raczej odwołanie do logiki funkcjonalnej z próbami zarządzania (ale nie rządzenia) kryzysem. Komisja Europejska pomimo nawet deklarowanych chęci w tym zakresie nie przejęła władzy nad kryzysem, ale ograniczyła się do koordynacji działań państw i instytucji UE, wydawania zaleceń, czy propozycji. Decyzje dotyczące ograniczeń wewnętrznych (np. dotyczących gospodarki czy praw obywatelskich), jak i zewnętrznych (np. czasowe zamknięcie granic państwowych, kwarantanna dla wjeżdżających itp.) były w rękach państw członkowskich.

\section{Bibliografia}

A pharmaceutical strategy for Europe (2021), European Commision, https://ec.europa.eu/health/ human-use/strategy en, 16.06.2021.

Borkowski P. J. (2007), Polityczne teorie integracji międzynarodowej, Wydawnictwo Difin, Warszawa.

Coronavirus: EU mobilises $€ 10$ million for research (2020), European Commission, https:// ec.europa.eu/info/news/coronavirus-eu-mobilises-eur10-million-for-research-2020-jan-31_ en, 6.10.2020.

COVID-19: Commission steps up research funding and selects 17 projects in vaccine development, treatment and diagnostics (2020), European Commission - Press Release, Brussels 6 March 2020, https://ec.europa.eu/commission/presscorner/detail/en/ip_20_386, 5.10.2020.

Czachór Z. (2013), Kryzys i zaburzona dynamika Unii Europejskiej, Dom Wydawniczy Elipsa, Warszawa.

Czaputowicz J. (2008), Teorie stosunków międzynarodowych. Krytyka i systematyzacja, Wydawnictwo Naukowe PWN, Warszawa.

Czaputowicz J. (2010), Perspektywy teoretyczne w studiach europejskich, w: Studia europejskie. Zagadnienia metodologiczne, red. K. A. Wojtaszczyk, W. Jakubowski, Wydawnictwa Akademickie i Profesjonalne, Warszawa.

Czaputowicz J. (2018), Teorie integracji europejskiej, Wydawnictwo Naukowe PWN, Warszawa. 
Decyzja Komisji (UE) 2020/491 z dnia 3 kwietnia 2020 r. w sprawie zwolnienia przywozu z należności celnych przywozowych i z VAT w odniesieniu do towarów potrzebnych do zwalczania skutków epidemii COVID-19 w 2020 r.

Decyzja wykonawcza Komisji (UE) 2020/1023 z dnia 15 lipca 2020 r. zmieniajaca decyzję wykonawcza 2019/1765 w zakresie transgranicznej wymiany danych między krajowymi aplikacjami mobilnymi stużacymi do ustalania kontaktów zakaźnych i ostrzegania w związku ze zwalczaniem pandemii COVID-19, Dz. U. L 227 I z 16.07.2020.

EU Strategy for COVID-19 vaccines. Communication from the Commission to the European Parliament, the European Council, the Council and the European Investment Bank (2020), Brussels, 17.6.2020, $\operatorname{COM}(2020) 245$ final, https://eur-lex.europa.eu/legal-content/EN/ $\mathrm{TXT} /$ ?uri=CELEX\%3A52020DC0245, 12.04.2021.

Europe's moment: Repair and Prepare for the Next Generation, Communication from The Commission to The European Parliament, The European Council, The Council, The European Economic and Social Committe and The Committee Of The Regions, Brussels 27.5.2020, COM, s.14-15 (2020) 456 final, https://eur-lex.europa.eu/legal-content/EN/TXT/PDF/?uri=CELEX :52020DC0456\&from=EN, 11.10.2020.

Ex-post evaluation of the Public Health Programme (PHP) 2003-2008. Final report (2011), DG SANCO, March $2011 \mathrm{https://ec.europa.eu/health/sites/default/files/programme/docs/ex}$ post_evaluation_en.pdf, 27.05.2021.

Foster R., Grzymski J., Brusenbauch Meislová M. (2021), The Limits of EUropean Legitimacy: On Populism and Technocracy. Introduction to the Special Issue, "Journal of Contemporary European Research" 17 (2).

Góralczyk B. (2021), Świat Narodów Zagubionych, wywiad rzekę przeprowadziła Natalia Kołodyńska-Magdziarz, Wydawnictwo Nowej Konfederacji, Warszawa.

Konopacki S. (1998a), Funkcjonalistyczna teoria integracji politycznej Davida Mitrany'ego, „Studia Europejskie", nr 2.

Konopacki S. (1998b), Neofunkcjonalistyczna teoria integracji politycznej Ernsta Haasa i Leona Lindberga, „Studia Europejskie”, nr 3.

Krótkoterminowa gotowość UE $w$ dziedzinie zdrowia na wypadek występowania ognisk COVID-19. Komunikat Komisji do Parlamentu Europejskiego, Rady, Europejskiego Komitetu Ekonomiczno-Społecznego i Komitetu Regionów (2020), Bruksela dnia 15.7.2020 r., COM (2020) 318 final, https://eur-lex.europa.eu/legal-content/PL/TXT/?uri=CELEX:52020DC0318, 29.04.2021.

Mieńkowska-Norkiene R. (2020), Federalizacja Unii Europejskiej - fakt dokonany, kryzysowa konieczność czy mission impossible, w: Perspektywy ustrojowe Unii Europejskiej, red. J. F. Czub, P. Tosiek, Oficyna Wydawnicza ASPRA-JR, Warszawa.

Pandemia dała Unii nauczkę, jak postępować z autorytaryzmami (2020), z Paolą Mattei rozmawia Jakub Bodziony, „Kultura Liberalna”, nr 615 (45/2020), https://kulturaliberalna.pl/2020/10/20/ mattei-pandemia-dala-unii-nauczke-jak-postepowac-z-autorytaryzmami/, 24.01.2021.

Preparedness for COVID-19 vaccination strategies and vaccine deployment (2020), Communication From The Commission To The European Parliament And The Council, Brussels, 15.10.2020, $\operatorname{COM(2020)} 680$ final, https://ec.europa.eu/health/sites/health/files/vaccination/docs/2020_ strategies_deployment_en.pdf, 3.11.2020.

Rossa J., Marcinkowski T. (2020), Wprowadzenie oraz tezy o socjologii bezpieczeństwa, w: Rozwój na peryferiach? Rozwój czy maldevelopment?, t. III, red. J. Rossa, T. Marcinkowski, Wydawnictwo Akademii im. Jakuba z Paradyża, Gorzów Wielkopolski.

Rozporzadzenie Parlamentu Europejskiego i Rady (UE) 2021/522 z dnia 24 marca 2021 r. w sprawie ustanowienia Programu dziatań Unii w dziedzinie zdrowia (,Program UE dla zdrowia”) na lata 2021-2027 oraz uchylenia rozporządzenia (UE) nr 282/2014, Dziennik Urzędowy Unii 
Europejskiej L 107/1, 26.03.2021, https://eur-lex.europa.eu/legal-content/EN/TXT/?uri=uriserv:OJ.L_.2021.107.01.0001.01.ENG, 27.05.2021.

Rozporzadzenie wykonawcze Komisji (UE) 2020/568 z dnia 23 kwietnia 2020 r. uzależniajace wywóz niektórych produktów od wydania pozwolenia na wywóz.

Ruszkowski J. (2007), Wstęp do studiów europejskich, Wydawnictwo Naukowe PWN, Warszawa.

Sipiczki A., Lannoo K. (2021), The EU Health Union in search of a definition and an open discussion, CEPS 12 May 2021, https://www.ceps.eu/the-eu-health-union-in-search-of-a-definition-and-an-open-discussion/, 7.06.2021.

Strategia farmaceutyczna dla Europy, Komunikat Komisji do Parlamentu Europejskiego, Rady, Europejskiego Komitetu Ekonomiczno-Społecznego i Komitetu Regionów, COM (2020) 761 final (2020), Bruksela. 25.11.2020 r.

Surmaczyński M. (2010), Podstawowe problemy metodologiczne nauk społeczno-politycznych, Wydawnictwo Uniwersytetu Wrocławskiego, Wrocław.

Tosiek P. (2019), Perspektywy federalizacji systemu instytucjonalnego Unii Europejskiej, w: Instytucjonalizacja procesów integracji europejskiej. Wybrane zagadnienia teoretyczne i funkcjonalne, red. T. Kownacki, A. Wierzchowska, Dom Wydawniczy Elipsa, Warszawa.

Tosiek P. (2018), Postkryzysowa architektura Unii Europejskiej: model neomiędzyrzadowy czy plurilateralny?, w: Kryzysy w Unii Europejskiej w drugiej dekadzie XXI wieku. Uwarunkowaniaprzebieg - implikacje, red. T. Kubin, M. Stolarczyk, Wydawnictwo Uniwersytetu Śląskiego, Katowice.

Traktat o funkcjonowaniu Unii Europejskiej, Dziennik Urzędowy Unii Europejskiej C 326/47, 26.10.2012.

Veugelers R., Zachmann G. (2020), Racing against COVID-19: a vaccines strategy for Europe, Policy Contribution 07/2020, Bruegel 2020, https://www.bruegel.org/2020/04/covid-19-vaccines-strategy/, 22.05.2021.

Walka z dezinformacja wokót COVID-19 - dajemy dojść do głosu faktom (2020), Wspólny Komunikat do Parlamentu Europejskiego, Rady Europejskiej, Rady, Europejskiego Komitetu Społecznoekonomicznego i Komitetu Regionów, Bruksela dnia 10.6.2020, JOIN (2020) 8 final, https://eur-lex.europa.eu/legal-content/PL/TXT/?uri=CELEX\%3A52020JC0008, 11.05.2021.

Wniosek Rozporzadzenie Parlamentu Europejskiego i Rady w sprawie ustanowienia Programu działań Unii $w$ dziedzinie zdrowia na lata 2021-2027 oraz uchylenia rozporzadzenia (UE) $n r$ 282/2014 (,,Program UE dla zdrowia”), COM (2020) 405 final, 2020/0102COD, Bruksela, dnia 28.05.2020, https://eur-lex.europa.eu/legal-content/EN/TXT/?uri=CELEX:52020PC0405, 27.05.2021.

Wszyscy chca być suwerenni (2021), z Janem Zielonką rozmawia Tomasz Sawczuk, „Kultura Liberalna", nr 640 (15/2021), https://kulturaliberalna.pl/2021/04/13/wszyscy-chca-byc-suwerenni/, 24.04.2021.

\section{Streszczenie}

Kryzys pandemiczny postawił przed Unią Europejką zupełnie nowe wyzwania. Pojawiło się pytanie o to jaka powinna być właściwa reakcja na zagrożenie dotyczące życia i zdrowia Europejczyków. Na jakim poziomie powinny być podejmowane strategiczne działania: europejskim czy krajowym. Wraz z rozwojem pandemii, jej transgranicznym i bezprecedensowym charakterem pojawiło się jednak wyczekiwanie działań ze strony instytucji unijnych. W artykule ukazano reakcję Unii Europejskiej w obszarze zdrowia publicznego na kryzys pandemiczny w pierwszym roku pandemii. W oparciu o analizę dokumentów unijnych przedstawiono główne 
kierunki proponowanych działań. Ukazano w jaki sposób poszukiwano rozwiązań funkcjonalnych w trakcie realizacji działań antykryzysowych. Dodatkowo przedstawiono w jaki sposób pandemia miała wpływ na rozwój unijnej polityki zdrowotnej (np. EU4Health czy strategię farmaceutyczną).

Słowa kluczowe: Unia Europejska, kryzys, covid 19, zdrowie publiczne, funkcjonalizm

\title{
The anti-crisis policy of the European Union in the face of a pandemic SARS CoV-2 in the area of public health in 2020. In search of functional solutions
}

\begin{abstract}
Summary
The pandemic crisis has created completely new challenges for the European Union. The question has arisen as to what should be the appropriate response to a threat to the life and health of Europeans. At which level should strategic action be taken: European or national. However, with the development of the pandemic, its cross-border and unprecedented nature, many citizens started to expect action from the EU institutions. This paper presents the public health response of the European Union to the pandemic crisis in the first year of the pandemic. It presents the main directions of proposed actions, based on the analysis of EU documents. It shows how functional solutions were sought during the implementation of anti-crisis actions. Additionally, it presents how the pandemic has influenced the development of EU health policy (e.g. EU4Health or pharmaceutical strategy).
\end{abstract}

Key words: European Union, crisis, covid 19, public health, functionalism 